Original Article

\title{
Dehydration, skeletal muscle damage and inflammation before the competitions among the elite wrestlers
}

\author{
Isik OzKan, $\mathrm{PhD}^{1)^{*}}$, Cicioglu H. IBrahim ${ }^{2)}$ \\ 1) School of Physical Education and Sports, Afyon Kocatepe University: Afyonkarahisar 03200, Turkey \\ 2) School of Physical Education and Sports, Gazi University, Turkey
}

\begin{abstract}
Purpose] The present study aimed to identify weight-loss and hydration levels before competitions among elite wrestlers and determine the skeletal muscle damage and inflammation levels after dehydration. [Subjects] Seventy-two elite wrestlers who participated in the Turkish Wrestling Championship. [Methods] With the help of specialists, $5 \mathrm{cc}$ of blood were drawn from the forearm veins of the wrestlers. Laboratory analyses of $\mathrm{Na}^{+}$, BUN, Glucose, CK, LDH, AST, ALT, C-RP levels were performed. Using a mathematical formula for hydration the $\mathrm{P}_{\mathrm{Osm}}$ levels of the athletes were calculated. [Results] The wrestlers were divided into two groups based on hydration status. There were significant correlations between hydration indicators of $\mathrm{Na}^{+}, \mathrm{BUN}$ and PBWL values. There were significant differences between AST, LDH, CK values and skeletal muscle damage indicators of the two groups, but there were no significant differences between the inflammation levels and C-RP values of the groups. [Conclusion] No differences existed in inflammation levels among the wrestlers, although dehydrated wrestlers suffered from higher level of skeletal muscle damage than wrestlers who were not dehydrated.

Key words: Dehydration, Skeletal muscle damage, Inflammation
\end{abstract}

(This article was submitted Sep. 14, 2015, and was accepted Oct. 14, 2015)

\section{INTRODUCTION}

The amateur wrestling community and maybe the entire sports community across the world were shocked by the deaths of 3 college wresters in the USA in six weeks in 1997. The deaths of the athletes were attributed by autopsy to weight-loss performed in a short time the victims having undergone dehydration of up to $15 \%{ }^{1}$. Following these deaths in 1997 , the National Collegiate Athletic Association (NCAA) initiated and developed new safety precautions in order to prevent unsafe weight practices ${ }^{2)}$. After studies of this subject, NCAA decided that competition-weighing should be conducted nearer to the competitions and new weight classes should be determined by adding nearly $+3 \mathrm{~kg}$ to each weight class ${ }^{3}$. Besides, NCAA recommended that weekly weight-loss should not exceed $1.5 \%$ of body weight as a part of the Wrestling Weight Certification (WWC) program ${ }^{4}$. However, the most important reason why athletes lose weight is that they want to compete in the lowest weight-class possible, and they think that the time between weighing and competition ( $\sim 16$ hours) is sufficient for rehydration after dehydration $^{5)}$. Nevertheless, studies report that this time period of $\sim 16$ hours is not enough to regain the body-weight $\operatorname{los}^{6)}$ and dehydration decreases athletes' performances, too ${ }^{7)}$. It was reported that when athletes of particularly combat sports such as judo, karate, boxing and wrestling perform excessively severe dehydration in a short time (1-7 days), they undergo some hematologic changes ${ }^{8,9)}$. There would be changes not only in $\mathrm{P}_{\mathrm{Osm}}$ levels, but also in $\mathrm{Na}^{+}, \mathrm{BUN}$ and glucose levels due to $\mathrm{P}_{\mathrm{Osm}}{ }^{10,11)}$. It was reported that athletes who perform weight-loss before competitions undergo not only change their hydration status, but also experience health problems such as sleep disorders, learning and memory difficulties, anxiety, depression, irregular body temperature, vasoconstriction, low sexual performance and dysfunctions in skeletal muscles ${ }^{12)}$.

\footnotetext{
*Corresponding author. Isik Ozkan (E-mail: ozkanisik86@hotmail.com; oisik@aku.edu.tr)

(C)2016 The Society of Physical Therapy Science. Published by IPEC Inc.

This is an open-access article distributed under the terms of the Creative Commons Attribution Non-Commercial No Derivatives (by-nc-nd) License $<$ http://creativecommons.org/licenses/by-nc-nd/3.0/>.
} 
Skeletal muscle damage can be hematologically detected by analyzing serum levels of CK, and such indicators as LDH, AST and ALT enzymes in the cells of many tissues ${ }^{13)}$. The most important indicator of skeletal muscle damage is serum CK level, because CK in skeletal muscle tissues is the enzyme that exists in higher amounts in the sarcolemma and mitochondrial cells of healthy muscle cells, and is primarily responsible for regulating anaerobic metabolism ${ }^{14}$. Observing serum CK and LDH levels may provide useful information about the status of the muscles and their adaptation to physical load because serum CK and LDH levels demonstrate the degree of metabolic adaptation of skeletal muscles to physical exercise. Both enzymes exist in muscle metabolism and their serum intensity is rather low. These values increase considerably after intense exercise $^{15)}$.

In physical tissue damage and other inflammatory conditions, C-RP is the main acute phase protein and a very sensitive and objective indicator ${ }^{16,17)}$. Indeed, Abramson and Vaccarino reported that the C-RP level increased after one exercise dependent on the duration and intensity of the exercise ${ }^{18)}$. On the other hand, Booth et al. reported that C-RP, which was one of the indicators studied in a 12-day military exercise, was $5.00 \pm 5.9 \mathrm{~g} / \mathrm{L}$ before the military exercise, but $1.2 \pm 1.2 \mathrm{~g} / \mathrm{L}$ after the military exercise ${ }^{19}$ ). It was also reported that the serum C-RP level of athletes increased with one exercise protocol ${ }^{20)}$, but in prospective studies; that the serum C-RP level of the athletes decreased ${ }^{21)}$.

There are studies in literature of dehydration, skeletal muscle damage and inflammation among elite wrestlers ${ }^{22-24)}$. However, no study has been conducted to determine whether skeletal muscle damage or inflammation occur with dehydration. Accordingly, the present study aimed to identify weight-loss and hydration levels before competitions among elite wrestlers and explore skeletal muscle damage and inflammation levels after dehydration. Trainers and athletes will benefit from information on skeletal muscle damage and inflammation levels caused by dehydration.

\section{SUBJECTS AND METHODS}

The study subjects were 72 volunteer elite wrestlers who competed in the Turkish Inter-university Wrestling Championship A Division, who had at least 5 years sport experience and did at least one exercise on a daily basis. The participant athletes were asked not to use any kinds of medicine or ergogenic aids within 48 hours before competition-weighing in order to ensure standardization of the subjects and those who used medicines or ergogenic aids were excluded from the study. During the study period, no disease that could affect the blood values of the athletes was detected, but three athletes were excluded from the study because their CK levels were above 1,000 U/L (hyper-responder) and their values were considered as lost data. The study was completed with 69 elite wrestlers $(22.51 \pm 2.49$ years, $174.54 \pm 6.59 \mathrm{~cm}, 78.98 \pm 15.87 \mathrm{~kg}$ and $\mathrm{BMI}$ $\left.25.73 \pm 3.77 \mathrm{~kg} / \mathrm{m}^{2}\right)$.

The details of dehydration protocols (how long, between which time-periods, with what methods the elite wrestlers achieved weight-loss) were datails of dehydration protocols. Wrestlers reported that they lost weight 1-7 days before competitions through food and fluid restrictions, sauna and exhausting exercises. In the literature, euhydration is accepted to have a reference range of 280-290 mOsm/L. Thus, wrestlers with $\mathrm{P}_{\mathrm{Osm}} \leq 290$ were assigned to the dehydrated group and those with $\mathrm{P}_{\mathrm{Osm}}>290$ to the not dehydrated group ${ }^{25)}$. Dehydration was calculated using the formula below:

$\left.\mathrm{P}_{\text {Osm }}=(2 * \mathrm{NA})+(\mathrm{BUN} / 2.8)+(\text { Glucose } / 18)^{26}\right)$.

Casa et al. determined $1 \%$ of dehydration as satisfactory dehydration, $>1-3 \%$ of dehydration as mild dehydration, $>3-5 \%$ of dehydration as high dehydration, and $>5 \%$ of dehydration as severe dehydration ${ }^{27)}$. The percentage of Body Weight-Loss (PBWL) calculation was performed using the formula below:

Body Weight Change $=[($ Pre-Body Weight - Post-Body Weight $) /$ Pre-Body Weight $] \times 100$.

With the help of specialists, $5 \mathrm{cc}$ of blood was drawn from the forearm veins of the participant wrestlers into $8.5 \mathrm{~mL}$ tubes of a Vacuatiner blood collection system at the competition place and at the weighing time (one day before the competition, between 06:00 and 06:30 pm) and transported to the laboratory for centrifugation.

The blood samples were centrifuged with a Nüve NF-400 for 5 minutes at 4,000 RPM. For each athlete, serums extracted from blood was preserved in two different Eppendorf tubes under $-20{ }^{\circ} \mathrm{C}$ until the time of analysis. On the day of the analysis, samples were stood at room temperature for 1 hour and dissolved. Biochemical analyses [hydration indicators $\left(\mathrm{NA}^{+}, \mathrm{BUN}\right.$, Glucose) and analyses of Skeletal Muscle Damage indicators (AST, ALT, LDH, CK)] were performed using a Beckman Coulter AU2700 Plus biochemical auto-analyzer with Beckman Coulter kits, while hormone analyses were Roche Hitachi Cobas e601 auto-analyzer with Roche kits. C-RP analyses were performed using a Beckman Coulter IMMAGE 800 nephelometer autoanalyzer with Roche kits.

Data was tested for normality with the Kolmogorov Smirnov test. The independent Samples T Test was used to compare pairwise group variables that followed a normal distribution, and ANOVA was used for more than two groups. Following variance analyses; LSD multiple comparison test was employed in order to detect which measurement results caused the differences. Significance was accepted for values of $\mathrm{p}<0.05$ with a $95 \%$ confidence interval.

\section{RESULTS}

The responses to the questionnaire show that $55.07 \%$ of the elite wrestlers underwent fast weight-loss just before the 
competition (1-7 days) $(4.55 \% \pm 1.87)$. The wrestlers who underwent fast weight-loss had higher levels of $\mathrm{P}_{\text {Osm }}(296.05 \pm 3.14)$ above the upper limit of reference value (over 290) and suffered from dehydration. When intergroup hydration indicators were assessed, it was found that the $\mathrm{Na}^{+}, \mathrm{BUN}$ and PBWL levels of the wrestlers who were dehydrated were higher than those of the wrestlers who were not dehydrated $(\mathrm{p}<0.05)$, but no differences existed between the groups in terms of glucose levels ( $\mathrm{p}>0.05$; Table 1$)$.

When skeletal muscle damage and inflammation differences of the elite wrestlers were examined in relation to hydration status, differences in AST, LDH and CK levels $(p<0.05)$ were found, whereas no differences existed between the groups in terms of ALT and C-RP levels ( $p>0.05)$. Although there were differences between the groups in terms of AST (upper limit: $50 \mathrm{U} / \mathrm{L}$ ) and LDH (upper limit: $248 \mathrm{U} / \mathrm{L}$ ) values, these values were within the reference ranges. However, CK levels (upper limit: $171 \mathrm{U} / \mathrm{L}$ ) of both groups were higher than the reference range (Table 2).

According to the classification made by Casa et al. when investigating skeletal muscle damage and inflammation indicators of the athletes. There were differences between the groups in terms of AST, LDH, and CK levels $(\mathrm{p}<0.05)$, but there were no differences between the groups in terms of ALT and C-RP levels ( $p>0.05$; Table 3$)$.

\section{DISCUSSION}

Generally, many athletes perform fast weight-loss just before competitions (within 1-7 days) so that they can adapt themselves to different weight classes or compete against rivals who are less strong and weaker than them in order to gain advantage. Weight loss results in dehydration among the athletes by affecting their hydration levels negatively. Studies of dehydration report that dehydration can be detected with urine specific gravity (usg) as well as serum $\mathrm{P}_{\text {Osm }}{ }^{2,28)}$. When the $\mathrm{P}_{\text {Osm }}$ value is $\leq 290$, hydration is considered normal (euhydration), when it is $>290$, hydration is lower than the normal level

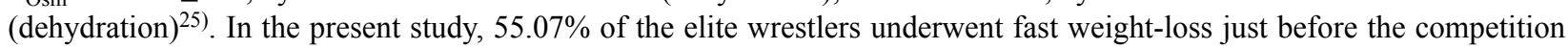

Table 1. Comparison of hydration indicators of wrestlers in terms of hydration status

\begin{tabular}{lllcc}
\hline & $\mathrm{N}$ & Hydration status & Reference range & $\bar{X} \pm \sigma$ \\
\hline $\mathrm{Na}^{+}$ & 31 & Dehydrated & $136-146$ & $142.5 \pm 1.6^{* *}$ \\
$(\mathrm{mmol} / \mathrm{L})$ & 38 & Not dehydrated & & $137.5 \pm 2.7$ \\
$\mathrm{BUN}$ & 31 & Dehydrated & $8-20$ & $16.4 \pm 3.4^{*}$ \\
$(\mathrm{mg} / \mathrm{dl})$ & 38 & Not dehydrated & & $14.3 \pm 3.6$ \\
Glucose & 31 & Dehydrated & $74-106$ & $97.0 \pm 15.8$ \\
$(\mathrm{mg} / \mathrm{dl})$ & 38 & Not dehydrated & & $97.1 \pm 12.5$ \\
& 31 & Dehydrated & $280-290$ & $296.1 \pm 3.1^{* *}$ \\
$\mathrm{P}_{\text {Osm }}(\mathrm{mOsm} / \mathrm{L})$ & 38 & Not dehydrated & & $285.3 \pm 5.2$ \\
& 31 & Dehydrated & - & $4.6 \pm 1.9^{* *}$ \\
PBWL $(\%)$ & 38 & Not dehydrated & & $1.0 \pm 1.3$ \\
\hline
\end{tabular}

${ }^{*} \mathrm{p}<0.05,{ }^{* *} \mathrm{p}<0.01, \bar{X}$ : mean, $\sigma:$ standard deviation, $\mathrm{Na}^{+}$: sodium, BUN: blood urea nitrogen, $\mathrm{P}_{\mathrm{Osm}}$ : plasma osmolarity, PBWL: percentage of body weight loss

Table 2. Comparison of skeletal muscle damage and inflammation indicators of the wrestlers in terms of $\mathrm{P}_{\mathrm{Osm}}$ levels

\begin{tabular}{lllcc}
\hline & $\mathrm{N}$ & $\mathrm{P}_{\text {Osm }}(\mathrm{mOsm} / \mathrm{L})$ & Reference range & $\bar{X} \pm \sigma$ \\
\hline AST & 31 & Dehydrated & $0-50$ & $24.9 \pm 6.3^{*}$ \\
$(\mathrm{U} / \mathrm{L})$ & 38 & Not dehydrated & & $21.5 \pm 4.5$ \\
$\mathrm{ALT}$ & 31 & Dehydrated & $0-50$ & $14.2 \pm 9.0$ \\
$(\mathrm{U} / \mathrm{L})$ & 38 & Not dehydrated & & $14.0 \pm 7.3$ \\
$\mathrm{LDH}$ & 31 & Dehydrated & $0-248$ & $207.2 \pm 37.2^{*}$ \\
$(\mathrm{U} / \mathrm{L})$ & 38 & Not dehydrated & & $185.8 \pm 27.6$ \\
$\mathrm{CK}$ & 31 & Dehydrated & $0-171$ & $421.0 \pm 174.0^{* *}$ \\
$(\mathrm{U} / \mathrm{L})$ & 38 & Not dehydrated & & $175.8 \pm 80.7$ \\
$\mathrm{C}-\mathrm{RP}$ & 31 & Dehydrated & $0-0.6$ & $0.3 \pm 0.3$ \\
$(\mathrm{mg} / \mathrm{dl})$ & 38 & Not dehydrated & & $0.3 \pm 0.3$ \\
\hline *p $<0.05, * * \mathrm{p}<0.01$, AST: aspartate aminotransferase, ALT: alanine aminotransferase, LDH: lac- \\
tate dehydrogenase, CK: creatine kinase, C-RP: c-reactive protein, $\mathrm{P}_{\text {Osm }}$ : plasma osmolarity
\end{tabular}


(1-7 days) (Table 1). The level of $\mathrm{P}_{\text {Osm }}$ of the wrestlers who underwent fast weight-loss was above the reference range (upper limit: 290) (296.05 \pm 3.14$)$ and they suffered dehydration of $4.55 \%$. These results of $\mathrm{P}_{\mathrm{Osm}}$ level of the wrestlers were similar to the results of usg ${ }^{29,30)}$.

Serum $\mathrm{Na}^{+}$and BUN levels were higher among the dehydrated wrestlers due to the increase in $\mathrm{P}_{\mathrm{Osm}}$, but no differences were seen in their glucose values (Table 1). In the literature the $\mathrm{Na}^{+}$reference range is reported to be between $136-146 \mathrm{mmol} / \mathrm{L}$. When the $\mathrm{Na}^{+}$concentration in a blood sample is $\leq 135 \mathrm{mmol} / \mathrm{L}$ it is defined as hyponatremia, and when it is $\geq 145$, it is defined as hypernatremia ${ }^{31)}$. It has been reported that the $\mathrm{Na}+$ concentration generally remains high due to long-term physical activities and excessive sweating and deficiency in all body fluids, and that $\mathrm{Na}^{+}$gradually increases with time ${ }^{32,33)}$. It has been recommended that during exercises, athletes should keep serum $\mathrm{Na}^{+}$concentration within the reference range through a controlled diet ${ }^{34)}$, otherwise nervousness, over-reaction, lethargy, muscle contraction, spasticity, convulsions, coma and even mortality may occur.

It is our opinion that the differences in BUN values resulted from the fact that wrestlers did long-term exhausting exercises and/or adhered to food and fluid restriction programs for dehydration. Since BUN is closely associated with the metabolic functions of the liver, and the filtrating and excreting functions of the kidneys, dehydration may increase ${ }^{35)}$. Indeed, the study of Mashiko et al. reported that according to measurements before and after a 20 day camp, rugby players lost weight and as a result their BUN levels decreased owing to weight loss ${ }^{36)}$.

The fact that there were no differences in the glucose values of the dehydrated wrestlers made us think that adrenaline increased by exercises converts glycogens stored in liver into glucose and glucose flows into blood with the help of glucagons and, as a result, regulates blood glucose levels. Differences in $\mathrm{Na}^{+}$and $\mathrm{BUN}$ values affect $\mathrm{P}_{\mathrm{Osm}}$ values of the athletes and change their hydration status. It is stated that dehydration of $2-3 \%$ causes cognitive disorders, irregular body temperature, cardiovascular dysfunctions as well as reduced endurance and weakens muscle strength ${ }^{37-39)}$. Besides, it is argued that dehydration may cause muscle damage among athletes.

There were significant differences in terms of the damage to skeletal muscles between the dehydrated wrestlers and not dehydrated wrestlers. This supports our study hypothesis. The differences between the hydration levels and the skeletal muscle damage was determined according to the classification of Casa et al., and in our study it was noted that there were significant differences in AST, LDH and CK, but no differences were found in ALT values (Tables 2 and 3) between the two groups. In the study of Nathwaniet et al., it was reported that serum levels of CK, LDH, AST, ALT increased following

Table 3. Comparison of skeletal muscle damage and inflammation indicators of the wrestlers in terms of PBWL classification

\begin{tabular}{|c|c|c|c|}
\hline & $\mathrm{N}$ & $\begin{array}{c}\text { PBWL (\%) } \\
\text { Classification }\end{array}$ & $\bar{X} \pm \sigma$ \\
\hline \multirow{4}{*}{ AST (U/L) } & 22 & $\% \quad 0-1$ & $22.0 \pm 4.3^{\mathrm{b}}$ \\
\hline & 18 & $\%>1-3$ & $19.9 \pm 5.0^{\mathrm{b}}$ \\
\hline & 19 & $\%>3-5$ & $25.6 \pm 5.5^{\mathrm{a}}$ \\
\hline & 10 & $\%>5$ & $26.3 \pm 5.6^{\mathrm{a}}$ \\
\hline \multirow{4}{*}{$\operatorname{ALT}(\mathrm{U} / \mathrm{L})$} & 22 & $\% \quad 0-1$ & $13.6 \pm 5.9$ \\
\hline & 18 & $\%>1-3$ & $14.1 \pm 7.6$ \\
\hline & 19 & $\%>3-5$ & $15.3 \pm 11.9$ \\
\hline & 10 & $\% \quad>5$ & $13.1 \pm 3.2$ \\
\hline \multirow{4}{*}{ LDH (U/L) } & 22 & $\% \quad 0-1$ & $182.6 \pm 24.1^{\mathrm{c}}$ \\
\hline & 18 & $\%>1-3$ & $188.0 \pm 38.6^{\mathrm{cb}}$ \\
\hline & 19 & $\%>3-5$ & $203.2 \pm 25.8^{\mathrm{ab}}$ \\
\hline & 10 & $\% \quad>5$ & $222.2 \pm 41.1^{\mathrm{a}}$ \\
\hline \multirow{4}{*}{$\mathrm{CK}(\mathrm{U} / \mathrm{L})$} & 22 & $\% \quad 0-1$ & $191.6 \pm 89.6^{\mathrm{b}}$ \\
\hline & 18 & $\%>1-3$ & $214.4 \pm 125.1^{\mathrm{b}}$ \\
\hline & 19 & $\%>3-5$ & $364.5 \pm 170.8^{\mathrm{a}}$ \\
\hline & 10 & $\% \quad>5$ & $472.9 \pm 226.3^{\mathrm{a}}$ \\
\hline \multirow{4}{*}{ C-RP (mg/dl) } & 22 & $\% \quad 0-1$ & $0.3 \pm 0.2$ \\
\hline & 18 & $\%>1-3$ & $0.4 \pm 0.3$ \\
\hline & 19 & $\%>3-5$ & $0.3 \pm 0.2$ \\
\hline & 10 & $\% \quad>5$ & $0.4 \pm 0.3$ \\
\hline
\end{tabular}

${ }^{\text {abc }}$ Represents the differences among the groups. AST: aspartate aminotransferase, ALT: alanine aminotransferase, LDH: lactate dehydrogenase, CK: Creatine Kinase, C-RP: C-reactive protein, PBWL: percentage of body weight loss 
muscle damage ${ }^{13}$. Under normal conditions, these elevated levels may be tolerated by the athletes with nutritional and relaxation programs, but among the dehydrated athletes, metabolism consumes low levels of carbohydrate due to food and fluid restrictions and uses an energy combination of fat and proteins; thus, glucose inhibition occurring with high plasma and free fat acids suggest that the damage to the muscles of the wrestlers would continue ${ }^{40,41)}$.

In clinical practice, CK, LDH, AST, ALT were commonly used for the diagnosis of skeletal muscle diseases and skeletal muscle tissue damage ${ }^{42}$. The most important indicator of muscle tissue damage is the serum CK level ${ }^{43}$. The LDH level is accepted to be a specific indicator of fatigue ${ }^{44,45}$. AST, being a cytoplasmic and mitochondrial enzyme, may increase in many clinical disorders, but ALT has been reported to be a specific indicator of liver damage ${ }^{13)}$. In our study, serum CK and LDH levels, important damage indicators, were higher in the dehydrated group than in the not dehydrated group. Among the dehydrated wrestlers, the high level of serum CK would have affected their performance negatively as well as restricted their movements because of muscle pains. It is also possible that the high level of serum LDH may cause wrestlers to be reluctant and/or unwilling for the next exercise. When aminotransferases were investigated, levels of AST and ALT were increased. However, while there was a significant difference in AST levels, no significant difference was seen in ALT level, which demonstrates that AST exists in higher amounts in skeletal muscles than ALT. Serum levels of all these damage indicators reduced after exercises and correlated with relaxation and feeding after exercises ${ }^{46}$. All of the participant wrestlers reported that they did daily exercises and training. Therefore; it is our opinion that the high level of skeletal muscle damage among the dehydrated wrestlers was caused by food and fluid restriction following exercises.

$\mathrm{C}-\mathrm{RP}$ is a major acute phase reactant that increases acutely and quickly in response to tissue damage and infection ${ }^{47)}$. In a systematic study of C-RP, it was found that as an acute phase response, C-RP temporally increased after a single exercise protocol among trained athletes. However, in prospective studies, it was demonstrated that C-RP (pretest-posttest) levels of the exercise groups reduced. In other words: although physical activity increased C-RP levels, chronic physical exercises reduced C-RP levels ${ }^{48)}$.

C-RP levels of the participant athletes of both groups were low and no difference existed between the groups. Considering the fact that these athletes had a sportive experience of at least five years, it was expected that they would have increased tissue oxygenation because of having regularly exercised for years.

UWW (United World Wrestling) shortened the resting-time in competitions of the wrestling championships, aiming at muscle endurance among the wrestlers. In a wrestling tournament, wrestlers usually have five bouts. Considering that bouts continue until the qualifications, semi-finals and even finals, time between bouts will be short, and resting-time not be sufficient for full recovery, lowering the performance of wrestlers who lose weight. Therefore, losing weight is not a rational competition approach.

In summary, fast and/or higher levels of weight loss before a competition produced differences in wrestlers' hydration indicator levels. Damage in skeletal muscles of the dehydrated wrestlers was greater than in those hydrated, but no difference was found in the inflammation levels of the groups. If it is necessary to lose weight before a competition, athletes should do it in a way to achieve a gradual and extended weight loss over a period of time depending on the weight loss targeted. In addition, while athletes are losing weight, they should keep levels of hydration and skeletal muscle damage indicators within their reference ranges through ergogenic aids. Thus, ergogenic aids will play a mediator role for wrestlers wishing to demonstrate maximum performance and to lead a healthy life.

\section{ACKNOWLEDGEMENTS}

I would like to thank the Biochemical Specialist of Provoncial Hospital of Afyon, Dr. Ramazan Akbay for his assessments and contributions in the biochemical analyses. The author also thanks to Sefa Demir and Emel Kaya who are working as nurses in the Afyon Kocatepe University hospital for their technical assistance in taking the blood samples.

\section{REFERENCES}

1) Remick D, Chancellor K, Pederson J, et al.: Hyperthermia and dehydration-related deaths associated with intentional rapid weight loss in three collegiate wrestlers-North Carolina, Wisconsin, and Michigan, November-December 1997, MMWR. Morbidity and mortality weekly report. JAMA-J Am Med Assoc, 1998, 279: 824-825.

2) Stuempfle KJ, Drury DG: Comparison of 3 methods to assess urine specific gravity in collegiate wrestlers. J Athl Train, 2003, 38: 315-319. [Medline]

3) Oppliger RA, Utter AC, Scott JR, et al.: NCAA rule change improves weight loss among national championship wrestlers. Med Sci Sports Exerc, 2006, 38: 963-970. [Medline] [CrossRef]

4) Utter AC: The New National Collegiate Athletic Association wrestling weight certification program and sport-seasonal changes in body composition of college wrestlers. J Strength Cond Res, 2001, 15: 296-301. [Medline] 
5) Wroble RR, Moxley DP: Acute weight gain and its relationship to success in high school wrestlers. Med Sci Sports Exerc, 1998, 30: 949-951. [Medline] [CrossRef]

6) Sagayama H, Yoshimura E, Yamada Y, et al.: Effects of rapid weight loss and regain on body composition and energy expenditure. Appl Physiol Nutr Metab, 2014, 39: 21-27. [Medline] [CrossRef]

7) Buford TW, Rossi SJ, Smith DB, et al.: The effect of a competitive wrestling season on body weight, hydration, and muscular performance in collegiate wrestlers. J Strength Cond Res, 2006, 20: 689-692. [Medline]

8) Rehrer NJ: Fluid and electrolyte balance in ultra-endurance sport. Sports Med, 2001, 31: 701-715. [Medline] [CrossRef]

9) Kingston JK: Hematologic and serum biochemical responses to exercise and training. Hinchcliff, KW, et al.: Equine exercise physiology. Philadelphia: Saunders Elsevier, 2008, pp 398-409.

10) Oppliger RA, Steen SA, Scott JR: Weight loss practices of college wrestlers. Int J Sport Nutr Exerc Metab, 2003, 13: 29-46. [Medline]

11) Alderman B, Landers DM, Carlson J, et al.: Factors related to rapid weight loss practices among international-style wrestlers. Med Sci Sports Exerc, 2004, 36: 249-252. [Medline] [CrossRef]

12) Isik O, Gokdemir K, Bastik $C$, et al.: A study on elite wrestlers: weight loss and depression. Nigde Univ J Phys Educ Sport Sci, 2013, 7: 216-223.

13) Nathwani RA, Pais S, Reynolds TB, et al.: Serum alanine aminotransferase in skeletal muscle diseases. Hepatology, 2005, 41: 380-382. [Medline] [CrossRef]

14) Ehlers GG, Ball TE, Liston L: Creatine kinase levels are elevated during 2-a-day practices in collegiate football players. J Athl Train, 2002, 37: 151-156. [Medline]

15) Coombes JS, McNaughton LR: Effects of branched-chain amino acid supplementation on serum creatine kinase and lactate dehydrogenase after prolonged exercise. J Sports Med Phys Fitness, 2000, 40: 240-246. [Medline]

16) Tamakoshi K, Yatsuya H, Kondo T, et al.: The metabolic syndrome is associated with elevated circulating C-reactive protein in healthy reference range, a systemic low-grade inflammatory state. Int J Obes Relat Metab Disord, 2003, 27 : 443-449. [Medline] [CrossRef]

17) Kim MC, Ahn CS, Lee HS, et al.: Change in C-reactive protein level according to amounts of exercise in chronic hemiparetic patients with cerebral infarct. J Phys Ther Sci, 2010, 22: 279-284. [CrossRef]

18) Abramson JL, Vaccarino V: Relationship between physical activity and inflammation among apparently healthy middle-aged and older US adults. Arch Intern Med, 2002, 162: 1286-1292. [Medline] [CrossRef]

19) Booth CK, Coad RA, Forbes-Ewan CH, et al.: The physiological and psychological effects of combat ration feeding during a 12-day training exercise in the tropics. Mil Med, 2003, 168: 63-70. [Medline]

20) Liesen H, Dufaux B, Hollmann W: Modifications of serum glycoproteins the days following a prolonged physical exercise and the influence of physical training. Eur J Appl Physiol Occup Physiol, 1977, 37: 243-254. [Medline] [CrossRef]

21) Lee SS, Yoo JH, Kang S, et al.: The effects of 12 weeks regular aerobic exercise on brain-derived neurotrophic factor and inflammatory factors in juvenile obesity and type 2 diabetes mellitus. J Phys Ther Sci, 2014, 26: 1199-1204. [Medline] [CrossRef]

22) Cengiz A, Demirhan B: Physiology of wrestlers' dehydration. Turk J Sport Exerc, 2013, 15: 1-10.

23) Isik O, Alpay CB, Hazar S, et al.: A study examining the effects of changed rules of wrestling competitions on the muscular damage levels of the elite wrestlers. TJSE, 2014, 16: 18-24. [CrossRef]

24) Cengiz A: Effects of self-selected dehydration and meaningful rehydration on anaerobic power and heart rate recovery of elite wrestlers. J Phys Ther Sci, 2015, 27: 1441-1444. [Medline] [CrossRef]

25) Popowski LA, Oppliger RA, Patrick Lambert G, et al.: Blood and urinary measures of hydration status during progressive acute dehydration. Med Sci Sports Exerc, 2001, 33: 747-753. [Medline] [CrossRef]

26) Yildirim I: Associations among dehydration, testosterone and stress hormones in terms of body weight loss before competition. Am J Med Sci, 2015, 350: 103-108.

27) Casa DJ, Armstrong LE, Hillman SK, et al.: National athletic trainers' association position statement: fluid replacement for athletes. J Athl Train, 2000, 35: 212-224. [Medline]

28) Kavouras SA: Assessing hydration status. Curr Opin Clin Nutr Metab Care, 2002, 5: 519-524. [Medline] [CrossRef]

29) Artioli GG, Iglesias RT, Franchini E, et al.: Rapid weight loss followed by recovery time does not affect judo-related performance. J Sports Sci, 2010, 28: 21-32. [Medline] [CrossRef] 
30) Demirkan E, Kutlu M, Koz M, et al.: The investigation of body composition and hydration changes in elite wrestlers. Selcuk Univ J Phys Educ Sports Sci, 2012, 14: 179-183.

31) Eijsvogels TM, Scholten RR, van Duijnhoven NT, et al.: Sex difference in fluid balance responses during prolonged exercise. Scand J Med Sci Sports, 2013, 23: 198-206. [Medline] [CrossRef]

32) Bergeron MF: Muscle cramps during exercise-is it fatigue or electrolyte deficit? Curr Sports Med Rep, 2008, 7: 50-55. [CrossRef]

33) Kim MH, Lee HJ: Effects of exercise intensity on hypertension prevalence in Korean men with high sodium intake. $\mathrm{J}$ Phys Ther Sci, 2015, 27: 2753-2757. [Medline] [CrossRef]

34) Kovacs L, Zamboni CB, Nunes LS, et al.: Sodium analysis in whole blood of athletes using NAA. AIP Conf Proc, 2010, 1265: 423-426. [CrossRef]

35) Gursoy S: The effects of exercise on total antioxidant capacity and serum lipid profile in regularly exercising sports students. Malatya University, Department of Medical Biochemistry, PhD Thesis, Malatya/Turkey, 2008.

36) Mashiko T, Umeda T, Nakaji S, et al.: Effects of exercise on the physical condition of college rugby players during summer training camp. Br J Sports Med, 2004, 38: 186-190. [Medline] [CrossRef]

37) Shirreffs SM: The importance of good hydration for work and exercise performance. Nutr Rev, 2005, 63: S14-S21. [Medline] [CrossRef]

38) Demirkan E, Koz M, Kutlu M: The effects of dehydration on athletic performance and monitoring hydration levels. Spormetre J Phys Educ Sports Sci, 2010, 8: 81-92.

39) Casa DJ, Stearns RL, Lopez RM, et al.: Influence of hydration on physiological function and performance during trail running in the heat. J Athl Train, 2010, 45: 147-156. [Medline] [CrossRef]

40) Bisschop PH, Pereira Arias AM, Ackermans MT, et al.: The effects of carbohydrate variation in isocaloric diets on glycogenolysis and gluconeogenesis in healthy men. J Clin Endocrinol Metab, 2000, 85: 1963-1967. [Medline]

41) Anderson DA, Shapiro JR, Lundgren JD, et al.: Self-reported dietary restraint is associated with elevated levels of salivary cortisol. Appetite, 2002, 38: 13-17. [Medline] [CrossRef]

42) Nie J, Tong TK, George K, et al.: Resting and post-exercise serum biomarkers of cardiac and skeletal muscle damage in adolescent runners. Scand J Med Sci Sports, 2011, 21: 625-629. [Medline] [CrossRef]

43) Han D, Cho B: A study of blood lactic acid and isokinetic muscular strength after maximal load exercise. J Phys Ther Sci, 2012, 24: 499-501. [CrossRef]

44) Seo B, Kim D, Choi D, et al.: The Effect of electrical stimulation on blood lactate after anaerobic muscle fatigue induced in Taekwondo athletes. J Phys Ther Sci, 2011, 23: 271-275. [CrossRef]

45) Alghadir AH, Gabr SA, Aly FA: The effects of four weeks aerobic training on saliva cortisol and testosterone in young healthy persons. J Phys Ther Sci, 2015, 27: 2029-2033. [Medline] [CrossRef]

46) Koutedakis Y, Raafat A, Sharp NC, et al.: Serum enzyme activities in individuals with different levels of physical fitness. J Sports Med Phys Fitness, 1993, 33: 252-257. [Medline]

47) Auer J, Berent R, Lassnig E, et al.: C-reactive protein and coronary artery disease. Jpn Heart J, 2002, 43: 607-619. [Medline] [CrossRef]

48) Kasapis C, Thompson PD: The effects of physical activity on serum C-reactive protein and inflammatory markers: a systematic review. J Am Coll Cardiol, 2005, 45: 1563-1569. [Medline] [CrossRef] 